\title{
An Experimental and Numerical Investigation of the Mechanical Properties of Spinal Cords
}

\section{Monika Ratajczak, Marek Malinowski, Romuald Będziński}

University of Zielona Góra, Faculty of Mechanical Engineering, Prof. Z. Szafrana 4, Zielona Gora, 65-516, Poland m.ratajczak@iizp.uz.zgora.pl, m.malinowski@ibem.uz.zgora.pl, r.bedzinski@ibem.uz.zgora.pl

\begin{abstract}
Studies concerning the mechanical properties of the spinal cord are crucial for the understanding of various related pathologies. The present study introduces the results of an analysis focused around the mechanical properties of the two types of the mammalian spinal cord: domestic pig (Sus scrofa f. domestica) and domestic rabbit (Oryctolagus cuniculus $f$. domesticus). The research has been conducted in an in vitro environment, and the freshly dissected cords have been subjected to uniaxial tension testing. A series of preliminary tests allowed for the selection of the optimum method for fixing the cord in the chuck of the testing machine. All preparations were tested for 3 hours after the death of the animal, while an appropriate level of hydration, and the temperature and the strain rate of 0.08s-1 have been maintained. The nonlinear response of the tested tissues has been obtained under the force-displacement conditions. On the basis of the experimental studies the mechanical properties of the samples have been described. Additionally, numerical calculations have been performed on a simplified model of the spinal cord with the use of the finite element (FE) method, which were finally compared with the actual behavior of the sample tissues. An analytical approach with the hyperelastic Ogden material model and FE model of the spinal cord were employed to derive mechanical properties of the tested spinal cords. The results demonstrate that a non-linear FE model is able to predict the mechanical behavior of the spinal cords in the uniaxial tension.
\end{abstract}

Keywords: spinal cord injury (SCI); nonlinear mechanical properties; finite element method (FEM); mechanical testing

\section{Introduction}

As a result of traffic accidents, falls from heights, as well as, various spinal diseases, spinal cord injuries (SCI) are reported with greater frequency. To understand the mechanisms of SCI and spinal cord compression syndromes, testing the mechanical properties of the spinal cord is necessary to facilitate the development of alternative tissue models. The early diagnosis of the type and 
extent of damage is essential for the development of proper methods of treatment [1]. The forces acting in the course of injury cause high stress and strain in the spinal cord tissue, and results in primary damage and a breach of the blood-spinal cord $[2,3]$. The resulting stress and deformation of the spinal cord is a major cause of neurological deficit and loss of motor and sensory function in patients with traumatic SCI [4]. The size of deformation, strain rate, size of axons and the local stress state in tissue have been proposed as the primary mechanism of damage to the spinal cord parenchyma cells during an injury [5]. Morbidities, such as degeneration, tumors, or cancers, can also cause the compression of the spinal tissue leading to its destruction. The intensity and duration of stress determine the size and potential reversibility of the spinal cord's dysfunction [6]. The mechanical tests are used to determine the mechanical properties of the spinal cord, allow for the understanding of the differences between healthy and pathological tissues, as well as the understanding of the mechanisms of an injury. The knowledge of the mechanical properties of the tissue can be used in robotsurgeon control systems, where the understanding of the deformation of the tissue is simply mandatory [7, 8, 9] and also allows one to specify the boundary conditions for the numerical analysis necessary to optimize the treatment process $[4,10,11]$. When it comes to any kind of reconstruction, the experimental results are a very important starting material for a given therapy [12, 13, 14]. The determination of the mechanical properties, as well as the understanding of the deformation response of the spinal cord is the basis for the construction of a regenerative bridge with a module fostering the nerve fiber regeneration [15]. The use of different strain rates during mechanical testing reflects the actual changes of the tissues in the aforementioned cases. The behavior of the spinal cord during a very slow strain rate can be interpreted in regard with various morbidities. The understanding of the mechanisms operating in traumatic injuries requires the use of a high-speed strain rate. On the other hand, the development of automatic surgical tools and robots $[16,17,18,19,20]$ and virtual reality techniques [21, 22] focuses on research in the moderate-speed deformation, which is important for surgical procedures [7].

Due to the limited availability of human specimens, testing techniques are generally limited to animal autopsy samples [23, 24, 25, 26, 27, 28, 29, 30]. A pioneer in conducting research on the mechanical properties of the spinal cord was Tunturi in 1978 [23]. Three years later, Hung and colleagues examined the spinal cord of cats and puppies in vivo [24, 25, 26]. Later, the mechanical properties of the spinal cord have been studied in vitro in different species, including: humans [31], adult and neonatal rats [27, 28], and cows [32]. In 2013 Luna et al. conducted in vivo and in vitro experiments on the spinal cords of lampreys [15]. The latest data come from 2014, where the mechanical properties of denticulate ligaments in pigs have been studied at different sections of the cervical region [33]. The results of all tests have been summarized in Table 5. According to Kiwerski et al., the heaviest neurological sequelae occur in the thoracic spine injuries; patients admitted with a paralysis are the largest group 
here, amounting to $71 \%$, and $17 \%$ are without neurological disorders [1]. The aim of the study was to investigate the mechanical properties of the spinal cords of domestic pigs (Sus scrofa $f$. domestica) and domestic rabbits (Oryctolagus cuniculus $f$. domesticus), the thoracic segments in the state of uniaxial tension, to be more precise. In the study, a moderate strain rate of $0.08 \mathrm{~s}^{-1}$ has been maintained. The spinal cords characteristics in the force elongation scenario have been obtained. An analysis of the behavior of individual tissue structures under the influence of a tensile force has been conducted, up to the moment of complete rupture of the sample. On the basis of own research and appropriate literature [4, $32,34,35,36,37]$, the finite element analysis of the tensile test of the spinal cord has been carried out in the ANSYS 5.7 software. A computer simulation has been used to explain certain behavior of the spinal cord structures in experimental studies employed on the sectional preparations. Selection of animal species was dictated by the anatomical similarity of the porcine spinal cord to the human one, as well as the DNA compliance of $94 \%$ [38, 39, 40]. In the case of rabbits, a relatively small number of studies have so far been performed on their cords [32, $36,37]$ compared to other species.

In the paper the experimental measurement of the mechanical properties of two types of the mammalian spinal cord were reported and numerical approach was presented and finite element modeling of mechanical parameters were derive. Uniaxial tension was conducted on spinal cords samples in testing machine ZWICK. The FE model of the spinal cord including only the gray and white matters (the first model) and the in the second model the dura mater and the pia mater were added. The hyperelastic constants (parameters) were calculated and numerical solutions were performed. The comparison of measurements and FE modeling results reveals the relationship between the mechanical properties and the studied structure of selected spinal cords.

\section{Materials and Methods}

Preparations were obtained right after slaughter. Intact spinal cords together with denticulate ligaments and dural sacs were dissected from healthy animals. The tissues were dissected from pigs (Figure 1), at the age of about one year and an average weight of around $100 \mathrm{~kg}$, and rabbits (Figure 2), with an average weight of about $3.5 \mathrm{~kg}$ at the age of about 6 months. All preparations were fresh, as the dissection was performed immediately after the death of the animal. The spinal column was purified from the musculus erector trunci and laminectomy was performed. 


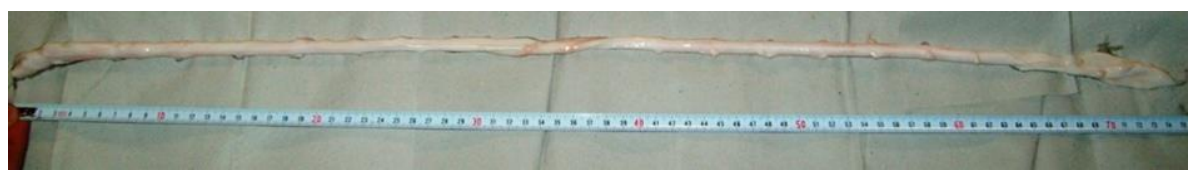

Figure 1

Dissected spinal cord of the domestic pig

During the process of preparation, a regularly exposed portion of the tissue was constantly moisturized with a saline solution to prevent drying of the sample. The maximum time of dissection in specimens was about 150 minutes. After the extirpation surgery, in order to verify the continuity of the spinal cords, all of them were tested under the stereomicroscope. The damaged samples were ultimately discarded.

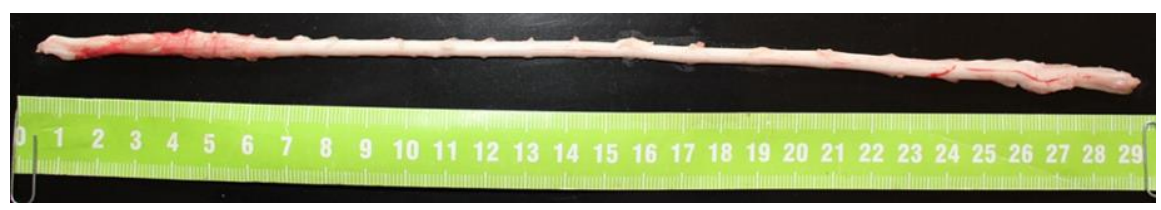

Figure 2

Dissected spinal cord of the domestic rabbit with a body weight of $4 \mathrm{~kg}$

The spinal cords were transferred to $0.9 \%$ sodium chloride environment at $37^{\circ} \mathrm{C}$, in order to achieve osmotic equilibrium and prevent the drying of samples. The distal ends of the spinal cord were dried with tissue paper. The samples were placed in a special attachment between two multi-grooved rubber pads in the jaws of the Zwick Z050 testing machine. To prevent slippage of the tissue during the measurement, two different methods of mounting the sample were employed: distal sections of the domestic pig spinal cord were wrapped around the polyethylene rollers (Figure 3), whereas the ends of the domestic rabbit's spinal cord tissue were glued with cyanoacrylate adhesive (Figure 4). We were very careful not to violate the samples during installation. During the measurements all samples were moistened with the saline solution.

For the present study quasi-static uniaxial tensile tests were performed $\left(\mathrm{n}_{1}=10\right.$ for porcine spinal cords and $\mathrm{n}_{2}=8$ for domestic rabbit's spinal cords). The spinal cords were elongated, without preconditioning, at a quasi-static rate of $0.05 \mathrm{~mm} / \mathrm{s}$. 


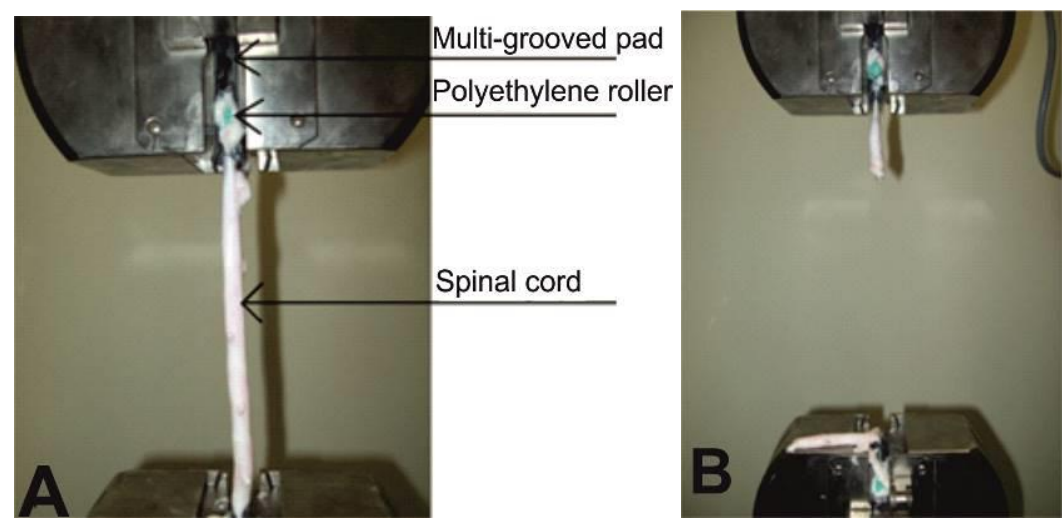

Figure 3

Preparation of the porcine spinal cord. A - at the time of the tensile test. B - rupture and the end of measurement
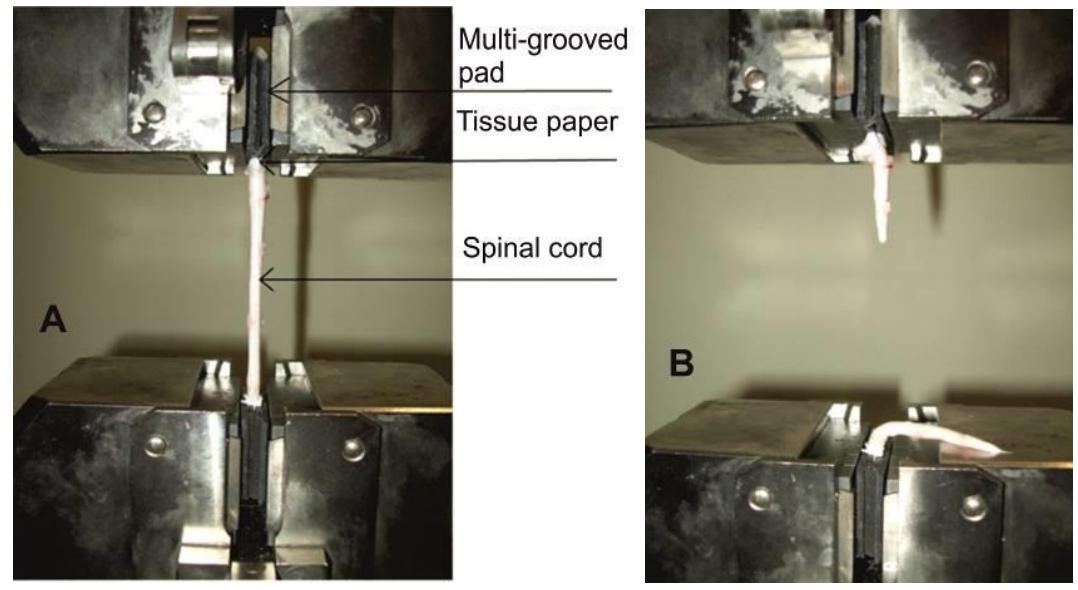

Figure 4

The preparation of the spinal cord of the domestic rabbit. A - at the time of the tensile test. B - rupture of the sample and the end of the measurement

\section{Experimental Results}

Ten samples of the domestic pig spinal cord were tested in the experiment. During the uniaxial tensile test the average pig spinal cords were deformed by $61.1 \%$. Examples of graphs in the force-displacement scenario have been shown in Fig. 5. On the A-B-C stretch, there is a clear increase in forces with relatively small displacement. In point $\mathrm{C}$, sample $\mathrm{A} 5$ and $\mathrm{A} 7$ sample in point $\mathrm{D}$ the tearing of the 
dura mater was observed. In the case of point D, sample, A5 and A7 sample in point $\mathrm{E}$ the complete rupture of the tissue took place.

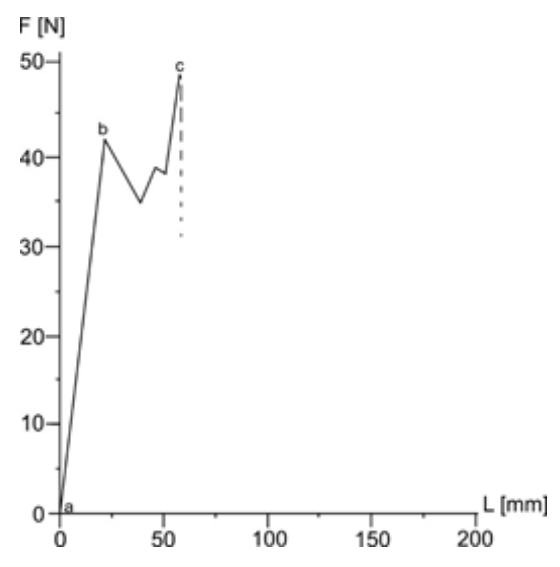

Sample A5

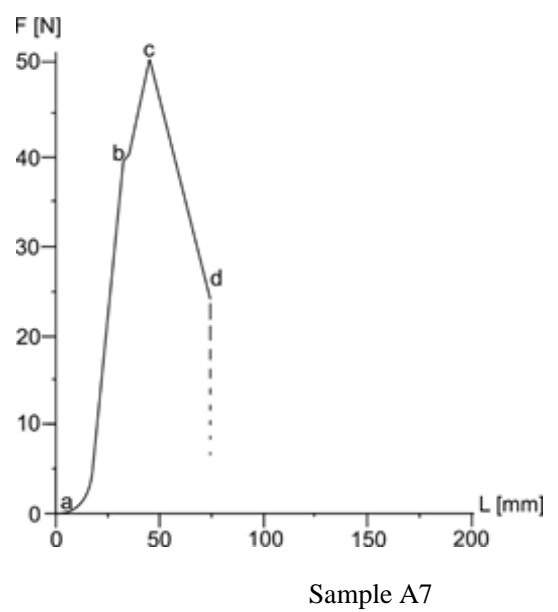

Sample A7

Figure 5

The characteristics of the force-displacement of the spinal cord [N-mm]

The results of all preparations tested are shown in Table 1. The maximum average force acting on the pig's spinal cord is $47 \mathrm{~N}$. Based on the mean from 10 measurements a value of Young's modulus of $0.323 \mathrm{MPa}$ was obtained.

Table 1

Summary of the results of the porcine spinal cord tests

\begin{tabular}{cccccc}
\hline No. of sample & $\begin{array}{c}\mathbf{F}_{\mathbf{m a x}} \\
{[\mathbf{N}]}\end{array}$ & $\begin{array}{c}\mathbf{l} \\
{[\mathbf{m m}]}\end{array}$ & $\begin{array}{c}\mathbf{\Delta}_{\mathbf{m a x}} \\
{[\mathbf{m m}]}\end{array}$ & $\begin{array}{c}\boldsymbol{\varepsilon}_{\mathbf{m a x}} \\
{[\mathbf{\%}]}\end{array}$ & $\begin{array}{c}\text { Young's modulus } \\
{[\mathbf{M P a}]}\end{array}$ \\
\hline $\mathbf{A 1}$ & 35.5 & 60 & 32 & 53 & 0.273 \\
\hline $\mathbf{A 2}$ & 41.0 & 224 & 148 & 66 & 0.254 \\
\hline $\mathbf{A 3}$ & 49.2 & 60 & 40 & 67 & 0.311 \\
\hline $\mathbf{A 4}$ & 55.8 & 203 & 130 & 64 & 0.356 \\
\hline $\mathbf{A 5}$ & 51.8 & 97 & 62 & 64 & 0.330 \\
\hline $\mathbf{A 6}$ & 47.0 & 128 & 88 & 69 & 0.278 \\
\hline $\mathbf{A 7}$ & 50.4 & 126 & 72 & 57 & 0.361 \\
\hline $\mathbf{A 8}$ & 50.8 & 66 & 40 & 61 & 0.340 \\
\hline $\mathbf{A 9}$ & 32.4 & 66 & 38 & 58 & 0.288 \\
\hline $\mathbf{A 1 0}$ & 56.1 & 23 & 12 & 52 & 0.440 \\
\hline
\end{tabular}

In a study of the mechanical properties of the rabbit spinal cord, we have used eight preparations. The uniaxial tension of the samples increased in length at $68 \%$ in average. The mean maximum force transmission through the spinal cord of the domestic rabbit was $6.75 \mathrm{~N}$. The mean of eight measurements was used to determine Young's modulus of $0.106 \mathrm{MPa}$. 

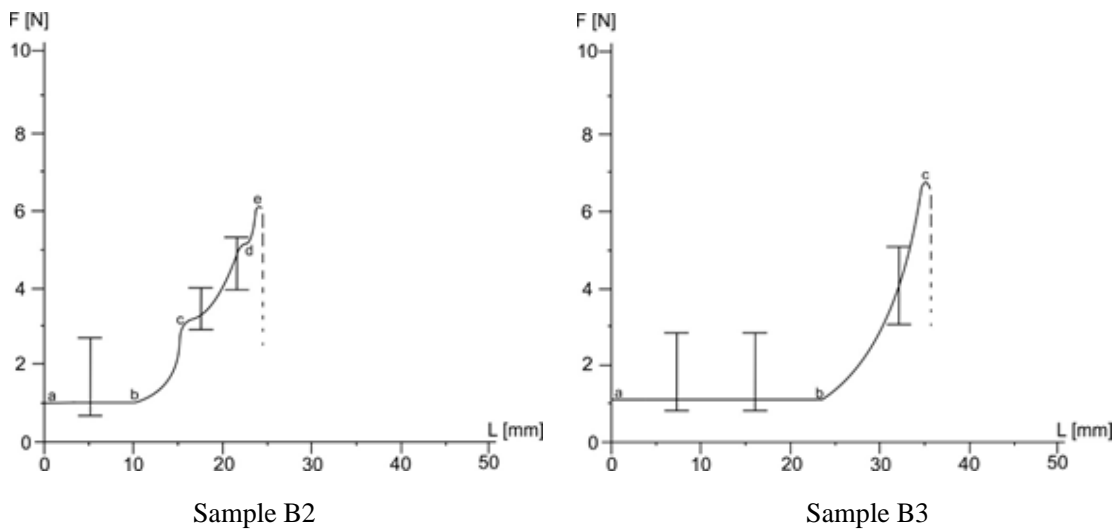

Figure 6

Characteristics of the force-displacement $[\mathrm{N}-\mathrm{mm}]$ for the spinal cord of the domestic rabbit

Examples of graphs from the study are shown in Figure 6. Points A - B pronounced displacement with a small change in force; point $\mathrm{D}$, sample B2 interruption of the dura mater, point $\mathrm{E}$, sample B2 and point $\mathrm{C}$, sample $\mathrm{B} 3$ - the complete rupture of the tissue.

Table 2

Summary of the experimental results from the scrutiny of the domestic rabbit's spinal cord

\begin{tabular}{rccccc}
\hline $\begin{array}{c}\text { No. of } \\
\text { sample }\end{array}$ & $\begin{array}{c}\mathbf{F}_{\mathbf{m a x}} \\
{[\mathbf{N}]}\end{array}$ & $\mathbf{1}[\mathbf{m m}]$ & $\mathbf{\Delta}_{\mathbf{m a x}}[\mathbf{m m}]$ & $\boldsymbol{\varepsilon}_{\mathbf{m a x}}[\boldsymbol{\%}]$ & $\begin{array}{c}\text { Young's modulus } \\
{[\mathbf{M P a}]}\end{array}$ \\
\hline $\mathbf{B 1}$ & 7.7 & 10 & 6 & 60 & 0.136 \\
\hline $\mathbf{B 2}$ & 6.7 & 38 & 24 & 63 & 0.113 \\
\hline $\mathbf{B 3}$ & 7.1 & 55 & 38 & 69 & 0.109 \\
\hline $\mathbf{B 4}$ & 5.2 & 40 & 27 & 68 & 0.081 \\
\hline B5 & 5.9 & 25 & 18 & 72 & 0.087 \\
\hline B6 & 6.2 & 75 & 50 & 67 & 0.098 \\
\hline B7 & 9.6 & 50 & 38 & 76 & 0.134 \\
\hline B8 & 5.6 & 58 & 40 & 69 & 0.086 \\
\hline
\end{tabular}

\section{The Boundary Conditions of Numerical Investigations and the Results of FEM Analysis}

The spinal cord is an inhomogeneous, composite material with a complex construction. Therefore, it is understandable that the biomechanics of the spinal cord injury can prove to be complex [41]. The use of numerical modeling of biological systems provides a more accurate analysis of the biomechanics of tissues $[4,9,10,11,42,43,44,45,46,47,48]$. Soft tissues are susceptible to 
deformation. The behavior of the materials at large scale deformation can be described using Ogden's hyperelastic model [31, 49, 50, 51]. The Ogden strain energy potential $W$ is defined as:

$W=\sum_{i=1}^{N} \frac{\mu_{i}}{\alpha_{i}^{2}}\left(\bar{\lambda}_{1}^{\alpha_{i}}+\bar{\lambda}_{2}^{\alpha_{i}}+\bar{\lambda}_{3}^{\alpha_{i}}-3\right)+\sum_{k=1}^{N} \frac{1}{d_{k}}(J-1)^{2 k}$

where: $\bar{\lambda}_{p}(p=1,2,3)$, are the deviatoric principal stretches, defined as $\bar{\lambda}_{p}=J^{-1 / 3} \lambda_{p}, \quad \lambda_{p}$ - principal stretches of the left Cauchy-Green tensor $\lambda_{p}=l_{p} / l_{p 0}$ the ratio of deformed length $l_{p}$ to the original length $l_{p 0}$ in principal directions, respectively $p=1,2,3, J$ - determinant of the elastic deformation gradient, $N, \mu_{p}, \alpha_{p}, d_{p}$ - material constants. The initial shear modulus $\mu$ is defined by $\mu=0.5 \sum_{i=1}^{N} \alpha_{i} \mu_{i}$ and initial bulk modulus $\kappa$ is defined by formula $\kappa=2 / d_{1}$. For a simplified, uniaxial tension, taking incompressibility into account, the relationship between the stress and stretch, Ogden's strain energy density function can be defined as follows:

$\sigma=\sum_{i=1}^{N} \frac{2 G_{i}}{\alpha_{i}}\left(\lambda_{1}^{\alpha_{i-1}}-\lambda_{1}^{-0.5 \alpha_{i-1}}\right)$

For $N=1$ and $\alpha_{1}=2$, the Ogden material model is equivalent to the NeoHookan model. For $N=2$ and $\alpha_{1}=2$ and $\alpha_{2}=-2$, the Ogden model is equivalent to the two parameter Mooney-Rivlin material model.

Computer simulations of the porcine spinal cord tension using a finite element method (FEM) were conducted in the ANSYS 5.7 software. Two numerical models were built of different spinal cord cross-sectional topologies. The first model included only the gray and white matters, while in the second model, the dura mater together with the pia mater were added. While taking into account the rheological properties of the materials, the numerical investigations incorporated the mechanical properties of the individual areas of the spinal cord [Table 3]. Parameters were determined on the basis of the experiments conducted by Ichihara et al. [34], Ozawa et al. [32], Wilcox et al. [35], as well as the work of Czyż et al. [4].

Table 3

The mechanical properties of the anatomical structures of the spinal cord [4], revised by the author

\begin{tabular}{cccc}
\hline Material & $\begin{array}{c}\text { Young's modulus } \\
{[\mathbf{M P a}]}\end{array}$ & Poisson's ratio & References \\
\hline Grey matter & 0.656 & 0.499 & Ichihara et al. 2003 [34] \\
\hline White matter & 0.277 & 0.499 & Ichihara et al. 2003 [34] \\
\hline Pia mater & 142 & 0.45 & Wilcox et al. 2003 [35] \\
\hline Dura mater & 2.3 & 0.3 & Ozawa et al. 2004 [32] \\
\hline
\end{tabular}


The analysis makes use of a simplified geometry in cross section (an ellipse) of the spinal cord. The geometric model in a 2D spinal cord was made in SolidWorks 2013, taking into account the thickness of the pia mater is constant and equals $0.1 \mathrm{~mm}$ and the dura mater equals $0.4 \mathrm{~mm}$ [52]. On the basis of the average sample size used in experimental testing, a 2D geometric model was created in ANSYS to the length of $100 \mathrm{~mm}$ to form the $3 \mathrm{D}$ geometry. The discrete model takes into account the longitudinal plane of symmetry. The tested experimental anatomical deformation of the preparations was above $60 \%$; thus, the values were increased and the numerical models were adjusted by stretching them up to $70 \mathrm{~mm}$. Finite elements: SOLID186 (20-nodes) and SHELL93 (8-nodes) were used. Numerical models contained from 13,450 to 21,220 finite elements.

The hyperelastic constitutive relation used to describe the tissue response was derived from the two parameters Ogden material model (Table 4). The Ogden strain energy potentials are nonlinear in terms of the constants. The MarquardtLevenberg method for nonlinear least squares fitting procedure was used.

Table 4

Fitted coefficients of mechanical properties Ogden hyperelastic model of the anatomical structures of the spinal cord

\begin{tabular}{cccc}
\hline Material & $\begin{array}{c}\text { Constant } \mu_{1} \\
{[\mathbf{k P a}]}\end{array}$ & $\begin{array}{c}\text { Constant } \alpha_{1} \\
{[\mathbf{k P a}]}\end{array}$ & $\begin{array}{c}\text { Constant } d_{1} \\
{[\mathbf{1} / \mathbf{k P a}]}\end{array}$ \\
\hline Grey matter & 32 & 4.7 & 6.4656 \\
\hline White matter & 32 & 4.7 & 6.4656 \\
\hline Pia mater & 0.13 & 0.0 & 299.85 \\
\hline Dura mater & 1200 & 16.2 & 0.1724 \\
\hline
\end{tabular}

In the model without the dural sac (Figure 7) the highest equivalent stress was observed in the gray matter at $0.488 \mathrm{MPa}$ (Figure 7A). Because of the boundary conditions adopted at the ends of the spinal cord model (no transverse displacements), relatively large equivalent strain, approximately $135 \%$ (Fig. 7B), appeared locally on the white matter. Within a significant distance from the boundary disturbance zone, the maximum equivalent strain occurred equal to approximately $85 \%$. 


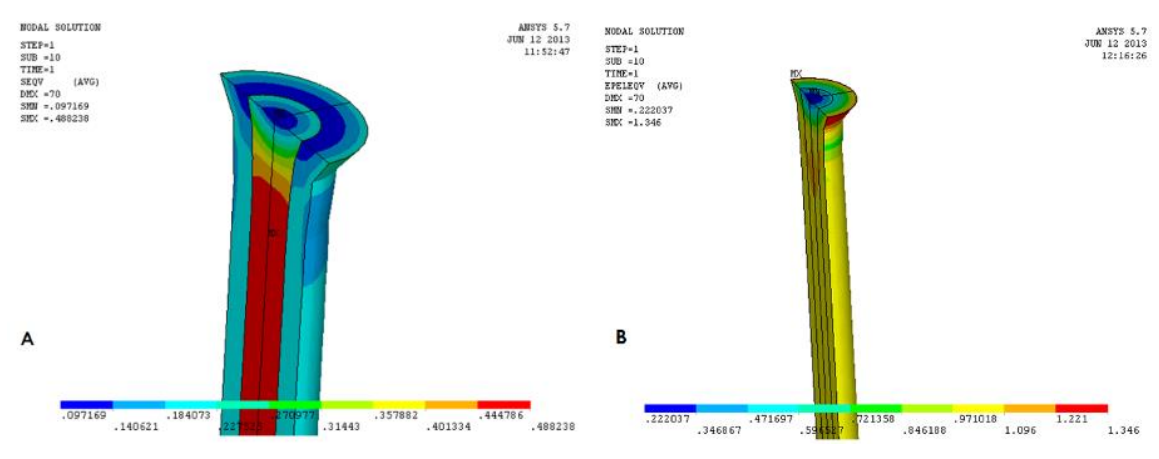

Figure 7

The spinal cord with only the gray and white matters: A - The equivalent stress [MPa] in a state of uniaxial tension, $\mathrm{B}$ - The equivalent strain $[\mathrm{x} 100=\%]$

In the dural sac's model (Figure 8), the maximum local equivalent stress in the clamping area, in the spinal cord equals $128.6 \mathrm{MPa}$. In this case, the boundary effect induced by the adopted boundary conditions (Figure 8A) is clearly visible. From a practical point of view, the most important data about the stress and the strain can be measured in the middle part of the model. In this area, the maximum equivalent stress is about $100 \mathrm{MPa}$ in the outer dura mater, with the strain of about $107 \%$. The gray matter and white matter stress did not exceed $0.03 \mathrm{MPa}$. The dural sac, with much higher values of Young's modulus and Poisson's ratios lower, when compared to the both kinds of matter, protects them from the high stress and, by doing so, also protects from the spinal cords rupture.

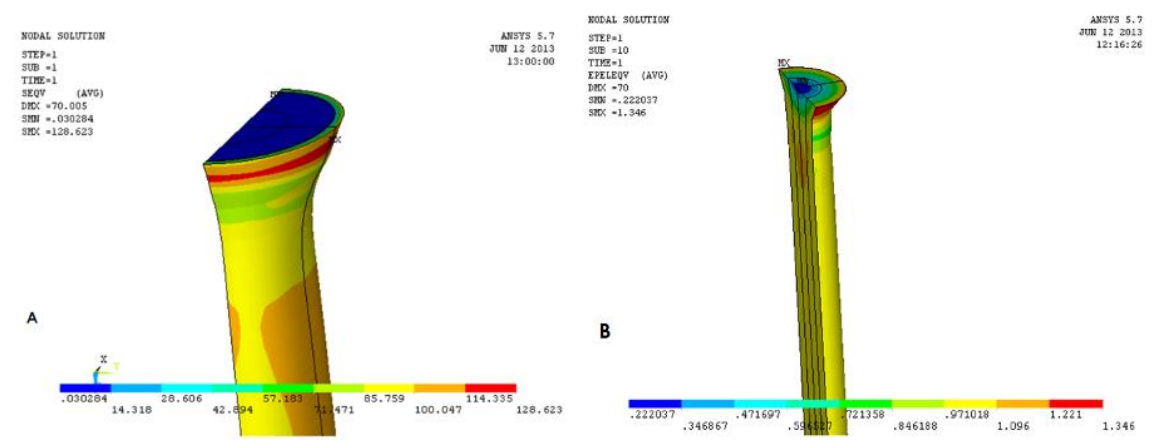

Figure 8

The spinal cord with the gray and white matters, the pia, mater and the dura mater. A - the equivalent stress $[\mathrm{MPa}] \mathrm{B}$ - the equivalent strain $[\mathrm{x} 100=\%]$

A force-displacement diagram has been obtained for the simulation of the spinal cord's tensile testing in the ANSYS 5.7 program (Figure 9). 


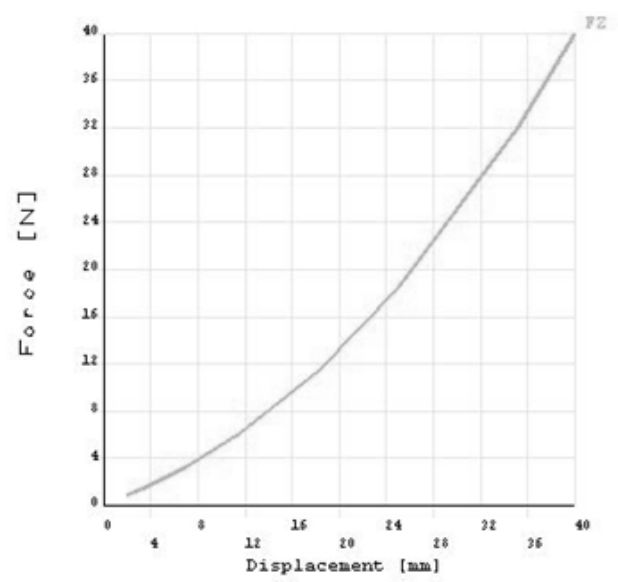

Figure 9

Characteristics of the axial force-displacement of the spinal cord obtained with the ANSYS software

In order to analyze the influence of the cerebrospinal fluid, when modeling the mechanisms of the spinal cord's injury, the next model includes such structures, as: the dura mater, the CSF, as well as, the white and gray matters, similar to what has been done by Maikos [53]. The CSF has been modeled using bulk modulus $6.67 \mathrm{kPa}$, Poisson's ratio 0.49 [53]. The properties of the spinal cords' remaining elements have been modeled in a way that is shown in Table 3. In this model (Figure 10), the largest reduced deformations caused by the tension testing were localized in the area of the CSF's occurrence. The equivalent and principal strains are presented in Figure 11. The measurement was performed in half of the length of the spinal cord in the cross section.
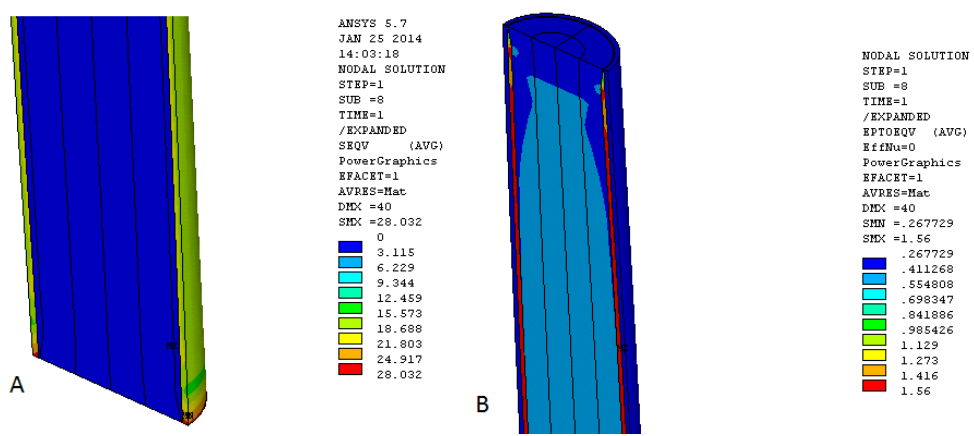

Figure 10

The spinal cord: the dura mater, the CSF, the white and gray matters: A - equivalent stress [MPa] in the state of uniaxial tension. $\mathrm{B}-$-equivalent strain $[\mathrm{x} 100=\%]$ 

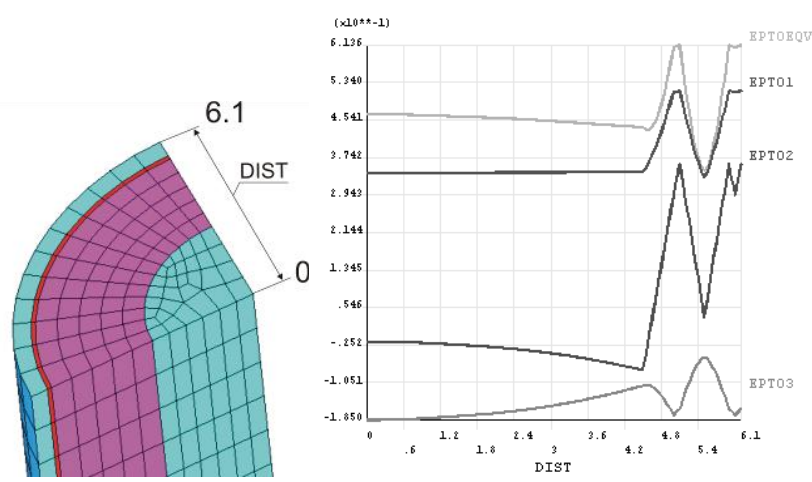

ANSYS 5.7

PEB 92014

12: $36: 25$

$\sin 1$

$\sin =1$

STB $=8$

PATH PLOT

PATH PLOT

$\operatorname{NOD} 2=1576$

Figure 11

Strains into cross section area of the spinal cord measured in the middle of the length of the cord, (equivalent von Mises strain EPTEQV, principal strain EPT01, 2, 3 [x100 =\%].

The analysis of the results has been carried out in the STATISTICA software, ver. 10.0 (StatSoft, Poland).

The in vitro tensile testing attempts have been compared with the data coming from the ANSYS program (Figure 12). In order to clearly present the obtained results, the nonlinear regression method has been employed.

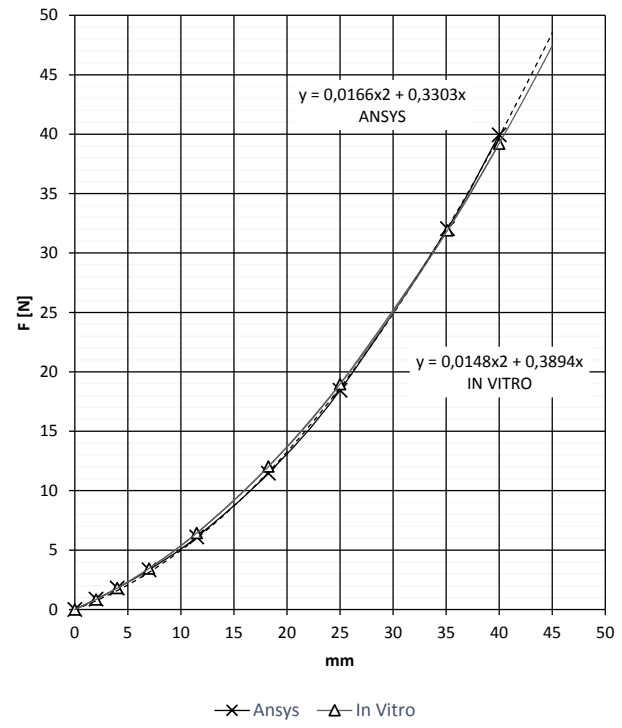

Figure 12

Comparison of FEM results and experimental data: Axial force $\mathrm{Fz}[\mathrm{N}]$ versus displacement [mm] 
The conducted comparative analyses show that the obtained experimental results are highly congruent with the data coming from the computer simulations.

\section{Discussion and Conclusions}

On the basis of the mechanical properties of the spinal cord in a state of uniaxial tension, nonlinear characteristics of the force-displacement system have been obtained. The nonlinear behavior of the spinal cord may arise from the extension of the individual fibers in the tissue during stretching.

The spinal cord experiences changes in its mechanical properties, after the death of the animal [54]. After 6 hours stiffness increases in all biological tissues [29]; therefore, all the samples were tested within three hours after death. During the test it was observed that, even though the sample was torn in the middle of the length measurement, the first dura mater injuries occurred near the area of the mechanical connection. Similarly, it has been demonstrated in a numerical model that the local stress concentrations are highest in the area close to the attachment of the tissue. Within the numerical model of the spinal cord with the dural sac, in the area of the primary damage to the dural sac the highest scalar strain took place. The spinal cord of the pig and the rabbit increased its length by more than half of its original length before the complete rupture. The average maximum force acting on the spinal cord of the pig was almost seven times higher than the maximum force acting on the spinal cord of the rabbit. In the computer simulation, after the addition of the dural sac to the model, the observed stress levels were much lower. This fact confirms the claims about the protective function of these structures.

Similar experiments using uniaxial tension on the spinal cord in an in vitro setting were carried out by Bilston and Thibault [31], Oakland et al. [29], and Clarke et al. [27] (Table 5). Young's modulus values that were obtained in this test amounted to $0.323 \mathrm{MPa}$ for the porcine spinal cord and $0.106 \mathrm{MPa}$ for the rabbit samples and were similar to the results obtained in vivo by Hung et al. [24] (Table $5)$. Strain values, which were obtained in the study $-61.1 \%$ for the porcine spinal cord and $68 \%$ for the spinal cord of the rabbit - were very different from the results listed in Table 5. A similar Young's modulus and tissue strain values were obtained by Ichihara et al. in 2001 [55], in the studies of the mechanical properties of the gray and white matters in an in vivo tension test (Table 6).

The results may differ, due to the differences in the scrutinized sections of the spinal cord, the use of different strain rates, the assembly of the samples in the testing machine, the testing apparatus, in general, the time elapsed since death, species differences, the physical condition and the age of animals and the quantity of the tested preparations [56]. 
Table 5

Summary of the results from the studies over the mechanical properties of the spinal cord - uniaxial tensile test [54], revised by the author

\begin{tabular}{|c|c|c|c|c|c|c|c|c|}
\hline 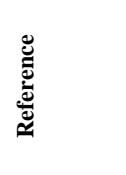 & 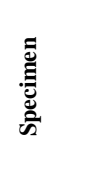 & 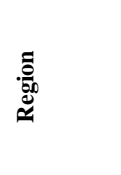 & 苛 & 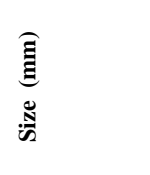 & 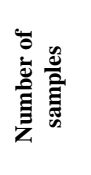 & 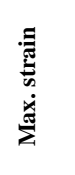 & 节 & 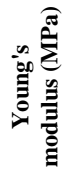 \\
\hline $\begin{array}{l}\text { Clarke et } \\
\text { al. }(2009)\end{array}$ & $\begin{array}{l}\text { Rat (14 } \\
\text { days) }\end{array}$ & $\begin{array}{c}\text { Not } \\
\text { specified }\end{array}$ & $\begin{array}{l}\text { In } \\
\text { vitro }\end{array}$ & Not specified & 8 & $5 \%$ & $\begin{array}{c}0.002 \mathrm{~s}^{1} \\
0.02 \mathrm{~s}^{-1} \\
0.2 \mathrm{~s}^{-1}\end{array}$ & $\begin{array}{l}0.010, \\
0.013, \\
0.015\end{array}$ \\
\hline $\begin{array}{c}\text { Oakland } \\
\text { et al. } \\
(2006)\end{array}$ & Cow & $\begin{array}{c}\text { Not } \\
\text { specified }\end{array}$ & $\begin{array}{c}\text { In } \\
\text { vitro }\end{array}$ & $130-80$ & 1 & $\begin{array}{c}\sim \\
8.5 \%\end{array}$ & $0.24 \mathrm{~s}^{-1}$ & 1.19 \\
\hline $\begin{array}{c}\text { Hung } e t \\
\text { al. } \\
(1981 \mathrm{c})\end{array}$ & Cat & $\mathrm{T} 8-\mathrm{L} 1$ & $\begin{array}{c}\text { In } \\
\text { vivo }\end{array}$ & 25 & 4 & $\begin{array}{c}8- \\
12 \%\end{array}$ & $\underset{1}{0.0008 \mathrm{~s}^{-}}$ & 0.4 \\
\hline $\begin{array}{c}\text { Hung and } \\
\text { Chang } \text { et } \\
\text { al. (1981a) }\end{array}$ & $\begin{array}{c}\text { Puppy } \\
(3- \\
5 \mathrm{~kg})\end{array}$ & $\mathrm{L} 1-\mathrm{L} 2$ & $\begin{array}{c}\text { In } \\
\text { vivo }\end{array}$ & 8 & 3 & $1.7 \%$ & $0.003 \mathrm{~s}^{-1}$ & 0.265 \\
\hline $\begin{array}{c}\text { Bilston } \\
\text { and } \\
\text { Thibault } \\
\text { (1996) }\end{array}$ & $\begin{array}{c}\text { Human } \\
(30-84 \\
\text { years })\end{array}$ & $\begin{array}{l}\text { Cervical } \\
\text { and } \\
\text { thoracic }\end{array}$ & $\begin{array}{c}\text { In } \\
\text { vitro }\end{array}$ & $30-45$ & 3 & $\sim 10 \%$ & $\begin{array}{c}0.048 \mathrm{~s}^{-1} \\
0.120 \mathrm{~s}^{-1} \\
0.225 \mathrm{~s}^{-1}\end{array}$ & $\begin{array}{l}1.02, \\
1.17, \\
1.37\end{array}$ \\
\hline $\begin{array}{c}\text { Polak et } \\
\text { al. } \\
(2014)\end{array}$ & $\begin{array}{c}\text { Domesti } \\
\text { c pig }\end{array}$ & $\begin{array}{c}\text { Cervical } \\
(\mathrm{C} 1-\mathrm{C} 7) \\
- \\
\text { denticulate } \\
\text { ligaments }\end{array}$ & $\begin{array}{c}\text { In } \\
\text { vitro }\end{array}$ & $\begin{array}{c}\text { Shown as a } \\
\text { triangle - the } \\
\text { calculated } \\
\text { cross- } \\
\text { sectional area } \\
\text { was } 0.45 \\
\mathrm{~mm}^{2}\end{array}$ & $\begin{array}{c}98 \\
\text { (mean) }\end{array}$ & $\begin{array}{c}2.35 \\
\%\end{array}$ & & 1.95 \\
\hline
\end{tabular}

Table 6

Mechanical properties of the gray and white matters [54]

\begin{tabular}{|c|c|c|c|c|c|c|c|c|}
\hline 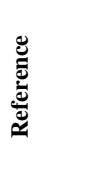 & 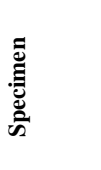 & 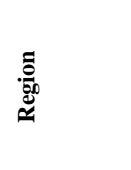 & 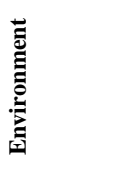 & ప్ & 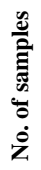 & 冚 & 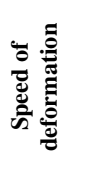 & 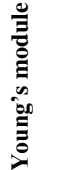 \\
\hline $\begin{array}{l}\text { Ichihara } \\
\text { et al. } \\
(2001)\end{array}$ & $\begin{array}{c}\text { Cow } \\
(2 \text { у. о. })\end{array}$ & $\begin{array}{l}\text { C3 white } \\
\text { matter }\end{array}$ & In vitro & $\begin{array}{c}17 \\
\mathrm{~mm}\end{array}$ & 6 & $\begin{array}{l}40 \% \text { (until } \\
\text { failure) }\end{array}$ & $0.05 \mathrm{~s}^{-1}$ & $\begin{array}{l}0.166 \\
\mathrm{MPa}\end{array}$ \\
\hline $\begin{array}{l}\text { Ichihara } \\
\text { et al. } \\
(2001)\end{array}$ & $\begin{array}{c}\text { Cow } \\
(2 \text { у. о. })\end{array}$ & $\begin{array}{c}\mathrm{C} 3 \\
\text { gray matter }\end{array}$ & In vitro & $\begin{array}{l}17 \\
\mathrm{~cm}\end{array}$ & 6 & $\begin{array}{l}55 \% \text { (until } \\
\text { failure) }\end{array}$ & $0.05 \mathrm{~s}^{-1}$ & $\begin{array}{l}0.025 \\
\mathrm{MPa}\end{array}$ \\
\hline
\end{tabular}


It is likely that there are significant differences in the gray to white matter ratios and the degree of vascularization between humans and different animal species. Estes and McElhaney, upon comparing the rhesus macaque (Macaca mulatta) tissues to human ones, established that human tissues are more deformable [27]. It should also be emphasized that in the case of an in vitro setting, the tissue response to the external load is a bit different than in the living body. Some of the many reasons for this may be, the degradation of the post-mortem tissue, or the pressure of blood perfusion in the spinal cord in a living body. Perfusion pressure can cause the hydraulic stiffness effect, which can possess the means of influencing the behavior of the tissue [28]. The results obtained in the work show the in vitro tissue response to the tensile forces. One should be careful in interpreting these results, when relating to human tissues. During a traumatic spinal cord injury, different forces may have an effect on the tissue, such as: compression, shearing, or twisting. In order to obtain valid results, when it comes to numeric models of the spinal cord, which would prove helpful in individual diagnostics and recuperation of the patients with the spinal cord injuries, it is necessary to include all of the parts constituting the spinal cord [33].

Further studies leading to a better understanding of the central nervous system should provide in situ measurements of constitutive compounds in the tissues [57], which take into account the effects of blood, with its pressure, as well as, the cerebrospinal fluid and the flow of both liquids, while also taking into account, the mechanotransduction process. The biomechanical configurations of living subjects are not yet well described, which makes numerical modeling all the more demanding. The development of automated equipment and computer-aided surgical treatments [58] emphasize the need for further studies of the mechanical properties of the spine - spinal cord interactions, with the inclusion of the intraoperative and external loads, e.g. surgical instruments. This knowledge is necessary to determine the boundary conditions for the mathematical descriptions of tissues for diagnosis, treatment and prognosis of injuries and diseases of the spinal cord. Determining these values will also allow for the prediction of the cord tissue's translocation during surgery, immediately after the injury, for example, and the removal of splinters of bone.

\section{Acknowledgement}

The authors wish to thank Dr. Zbigniew Zawada for providing animal samples.

\section{References}

[1] Kiwerski J, Kowalski M, Krakuski M, Schorzenia i urazy kręgosłupa, Wyd. PZWL, Warszawa, 1997

[2] Sharma HS, Pathophysiology of Blood-Spinal Cord Barrier in Traumatic Injury and Repair, in Banks WA (ed.), Current Pharmaceutical Design, Bentham Science Publishers, 11(11): 1353-1389, 2005 
[3] Maikos JT, Shreiber DI, Immediate Damage to the Blood Spinal Cord Barrier due to Mechanical Trauma, in Povlishock JT (ed.), Journal of Neurotrauma, National Neurotrauma Society, Mary Ann Liebert 24(3): 492-507, 2007

[4] Czyż M, Ścigała K, Jarmundowicz W, Będziński R, The Biomechanical Analysis of the Traumatic Cervical Spinal Cord Injury using Finite Element Approach, in Acta of Bioengineering and Biomechanics, Oficyna Wydawnicza Politechniki Wrocławskiej, Wrocław, 10(1): 43-54, 2008

[5] Galle B, Ouyang H, Shi R, Nauman E, Correlations between Tissue-Level Stresses and Strains and Cellular Damage within the Guinea Pig Spinal Cord White Matter, in Guilak F, Journal of Biomechanics 40: 3029-3033, 2007

[6] Lu J J, Benzel E C Biomechanics of the Spinal Cord, in Seminars in Spine Surgery 17(1):13-18, 2005

[7] Miller K, How to Test Very Soft Biological Tissues in Extension?, in Journal of Biomechanics, 34: 651-657, 2001

[8] Miller K, Wittek A, Joldes G, Biomechanics of the Brain for ComputerIntegrated Surgery, in Acta of Bioengineering and Biomechanics 12(2): 2537,2010

[9] Joldes GR, Wittek A, Miller K, Suite of Finite Element Algorithms for Accurate Computation of Soft Tissue Deformation for Surgical Simulation, in Medical Image Analysis 13: 912-919, 2009

[10] Czyż M, Ścigała K, Jarmundowicz W, Będziński R, Numerical Model of the Human Cervical Spinal Cord - the Development and Validation, Acta of Bioengineering and Biomechanics, 13(4): 51-58, 2011

[11] Czyż, M, Ścigała K, Będziński R, Jarmundowicz W, Finite Element Modelling of the Cervical Spinal Cord Injury - Clinical Assessment. Acta of Bioengineering and Biomechanics 14(4): 23-29, 2012

[12] Melińska A, Czamara A, Szuba L, Będziński R, Klempous R. Balance Assessment during the Landing Phase of Jump-Down in Healthy Men and Male Patients after Anterior Cruciate Ligament Reconstruction. Acta Polytechnica Hungarica 12(6): 77-91, 2015

[13] Bharathi S, Sudhakar R, Balas VE. Hand Vein-based Multimodal Biometric Recognition. Acta Polytechnica Hungarica 12 (6): 213-229, 2015

[14] Dobránszky J, Ring G, Bognár E, Kovács R, Bitay E. New Method for Evaluating the Visibility of Coronary Stents. Acta Polytechnica Hungarica 11(5):81-94, 2014

[15] Luna C, Detrick L, Shah SS, Cohen AH, Aranda-Espinoza H, Mechanical Properties of the Lamprey Spinal Cord: Uniaxial Loading and Physiological Strain, J Biomech 46(13): 2194-2200, 2013 
[16] Brett PN, Fraser CA, Henningan M, Griffiths MV, Kamel Y, Automatic Surgical Tools for Penetrating Flexible Tissues, IEEE Engineering Medicine and Biology 14(3): 264-270, 1995

[17] Villotte N, Glauser D, Flury P, Burckhardt CW, Conception of Stereotactic Instruments for the Neurosurgical Robot Minerva, Engineering in Medicine and Biology Society, $199214^{\text {th }}$ Annual International Conference of the IEEE 3: 1089-1090, 1992

[18] Taylor RH, Mitterlstadt BD, Paul HA, Hanson W, Kazanzides P, Zuhars JF, Williamson B, Musits BL, Glassman E, Bargar WL, An Image-Directed Robotic System for Precise Orthopaedic Surgery, in Taylor R. H., et al. (eds), Computer-Integrated Surgery: Technology and Clinical Applications, MIT Press, pp. 379-395, 1995

[19] Sackier JM, Wang Y, Robotically Assisted Laparoscopic Surgery: from Concept to Development, in Taylor RH, et al. (eds), Computer-Integrated Surgery: Technology and Clinical Applications. MIT Press, pp. 577-580, 1995

[20] Schenker PS, Das H, Ohm TR, A New Robot for High Dexterity Microsurgery, Proc CVRMed95. Lecture Notes Computer Science, 905, Springer-Verlag, pp. 115-122, 1995

[21] Burdea, G, Force and Touch feedback for Virtual Reality, Wiley, New York, 1996

[22] Joldes GR, Wittek A, Miller K, Real-Time Nonlinear Finite Element Computations on GPU - Application to Neurosurgical Simulation, Comput. Methods Appl. Mech. Engrg 199: 3305-3314, 2010

[23] Tunturi AR (1978), Elasticity of the Spinal Cord, Pia, and Denticulate Ligament in the Dog, Journal Neurosurgery, 48(6): 975-979, 1978

[24] Hung TK, Chang GL, Biomechanical and Neurological Response of the Spinal Cord of a Puppy to Uniaxial Tension, Journal of Biomechanical Engineering 103(1): 43-47, 1981a

[25] Hung TK, Chang GL, Chang JL, Albin MS, Stress-Strain Relationship and Neurological Sequelae of Uniaxial Elongation of the Spinal Cord of Cats, Surgical Neurology, 15(6): 471-476, 1981b

[26] Hung TK, Chang GL, Lin HS, Walter FR, Bunegin L, Stress-Strain Relationship of the Spinal Cord of Anesthetized Cats, Journal of Biomechanical Engineering, 14(4): 269-276, 1981c

[27] Clarke EC, Cheng S, Bilston LE, The Mechanical Properties of Neonatal Rat Spinal Cord in Vitro, and Comparisons with Adult, Elsevier, Journal of Biomechanics, Australia 42:1397-1402, 2009

[28] Fiford RJ, Bilston LE, The Mechanical Properties of Rat Spinal Cord in Vitro, Journal of Biomechanics, Australia, 38:1509-1515, 2005 
[29] Oakland RJ, Hall RM, Wilcox RK, Barton DC, The Biomechanical Response of Spinal Cord Tissue to Uniaxial Loading, Proceedings of the Institution of Mechanical Engineers [H], 220(4):489-492, 2006

[30] Shetye SS, Troyer KL, Streijger F, Lee JHT, Kwond BK, Cripton PA, Puttlitz CM, Nonlinear Viscoelastic Characterization of the Porcine Spinal Cord, Acta Biomaterialia 10(2): 792-797, 2014

[31] Bilston LE, Thibault LE, The Mechanical Properties of the Human Cervical Spinal Cord in Vitro, Annals of Biomedical Engineering, 24(1): 67-74, 1996

[32] Ozawa H, Matsumoto T, Ohashi T, Sato M, Kokubun S, Mechanical Properties and Function of the Spinal Pia Mater, Journal of Neurosurgery. Spine, 1: 122-127, 2004

[33] Polak K, Czyż M, Ścigała K, Jarmundowicz W, Będziński R, Biomechanical Characteristics of the Porcine Denticulate Ligament in Different Vertebral Levels of the Cervical Spine-Preliminary Results of an Experimental Study, Journal of the Mechanical Behavior of Biomedical Materials 34 (2014): 165-170, 2014

[34] Ichihara L, Taguchi T, Sakuramoto I, Kawano S, Kawai S, Mechanism of the Spinal Cord Injury and the Cervical Spondylotic Myelopathy: New Approach based on the Mechanical Features of the Spinal Cord White and Grey Matter, J. Neurosurg., 99, Suppl. 3: 278-285, 2003

[35] Wilcox RK, Bilston LE, Barton DC, Hall RM, Mathematical Model for the Viscoelastic Properties of Dura Matter, J Orthop. Sci., 8: 432-434, 2003

[36] Kwan M, Wall E, Massie J, Garfin S, Strain, Stress and Stretch of Peripheral Nerve: Rabbit Experiments in Vitro and in Vivo, Acta Orthopaedica Scandinavica, 63: 267-72, 1992

[37] Ozawa H, Matsumoto T, Ohashi T, Sato M, Kokubun S, Comparison of Spinal Cord Gray Matter and White Matter Softness: Measurement by Pipette Aspiration Method, Journal of Neurosurgery: Spine 95: 221-224, 2001

[38] Sheng, SR, Wang XY, Xu HZ, Zhu GQ, Zhou YF, Anatomy of Large Animal Spines and its Comparison to the Human Spine: a Systematic Review, Eur. Spine J. 19: 46-56, 2010

[39] Sparrey CJ, Keaveny TM, The Effect of Flash Freezing on Variability in Spinal Cord Compression Behavior, J. Biomech. Eng, 131: 111010, 2009

[40] Sparrey CJ, Keaveny TM, Compression Behavior of Porcine Spinal Cord White Matter, J. Biomech. 44: 1078-1082, 2011

[41] Maikos J, In Vivo Tissue Level Thresholds for Spinal Cord Injury, New Brunswick, New Jersey, 2007 
[42] Winkelstein BA, Myers BS, The Biomechanics of Cervical Spine Injury and Implications for Injury Prevention, Med Sci Sports Exerc 29(7 Suppl): S246-55, 1997

[43] Yoganandan N, Kumaresan S, Voo L, Pintar FA, Finite Element Model of the Human Lower Cervical Spine: Parametric Analysis of the C4-C6 unit, J. Biomech. Eng. 119(1): 87-92, 1997

[44] Willinger R, Kang HS, Diaw B, Three-Dimensional Human Head FiniteElement Model Validation against Two Experimental Impacts, Ann Biomed Eng 27(3): 403-410, 1999

[45] Wheeldon J, Khouphongsy P, Kumaresan S, Yoganandan, N, Pintar FA, Finite Element Model of Human Cervical Spinal Column, Biomed. Sci. Instrum. 36: 337-342, 2000

[46] Tillier Y, Paccinia A, Durand-Revilleb M, Baya F, Chenota JL, ThreeDimensional Finite Element Modelling for Soft Tissues Surgery 2003, International Congress Series 1256: 349-355, 2003

[47] Miller K, Chinzei K, Orgssengo G, Bednarz P, Mechanical Properties of Brain Tissue In-Vivo: Experiment and Computer Simulation, J. Biomech. 33(11): 1369-1376, 2000

[48] Miller K, Jia L, On the Prospect of Patient-Specific Biomechanics without Patient-Specific Properties of Tissues, 2013 Journal of the mechanical behavior of biomedical materials 27: 154-166, 2013

[49] Ogden, RW, Large Deformation Isotropic Elasticity - on the Correlation of Theory and Experiment for Incompressible Rubberlike Solids, Proceedings of the Royal Society London Series A 326: 565-584, 1972

[50] Fung YC, Biomechanics - Mechanical Properties of Living Tissues second ed., Springer-Verlag, New York, 1993

[51] Miller K, Chinzei K, Mechanical Properties of Brain Tissue in Tension, Journal of Biomechanics 35: 483-490, 2002

[52] Nicholas DS, Weller RO, The Fine Anatomy of the Human Spinal Meninges. A Light and Scanning Electron Microscopy Study, J. Neurosurg. 69: 276-282, 1988

[53] Maikos JT, Qian Zh, Metaxas D, Shreiber DI, Finite Element Analysis of Spinal Cord Injury in the Rat, Journal of Neurotrauma 25: 795-816, 2008

[54] Cheng S, Clarke EC, Bilston LE, Rheological Properties of the Tissues of the Central Nervous System, Medical Engineering \& Physics, Australia, 30: 1318-1337, 2008

[55] Ichihara K, Taguchi T, Shimada Y, Sakuramoto I, Kawano S, Kawai S, Gray Matter of the Bovine Cervical Spinal Cord is Mechanically more 
Rigid and Fragile than the White Matter, J Neurotrauma 18(3): 361-367, 2001

[56] Będziński R, Biomechanics, Komitet Mechaniki PAN, Wyd. IPPT PAN, Warsaw, 2001 (in Polish)

[57] Elliott NSJ, Bertram CD, Martin BA, Brodbelt AR, Syringomyelia: A Review of the Biomechanics, Journal of Fluids and Structures, 40(2013): 124, 2013

[58] Takács Á, Kovács L, Rudas IJ, Precup R, Haidegger T. Models for Force Control in Telesurgical Robot Systems. Acta Polytechnica Hungarica 12(8): 95-114, 2015 